\title{
Hubungan Kolesterol LDL dengan Derajat Retinopati Diabetik di Bagian Mata RSUP Dr. M. Djamil Padang Periode Januari- Desember 2015
}

\author{
Zacky Aulia Mursi ${ }^{1}$, Hendriati $^{2}$, Laila Isrona ${ }^{3}$
}

\begin{abstract}
Abstrak
Retinopati diabetik adalah salah satu komplikasi mikrovaskular Diabetes Melitus (DM) yang merupakan penyebab utama kebutaan pada orang dewasa. Kehilangan perisit adalah awal dari retinopati diabetik yang dapat dipengaruhi oleh modifikasi LDL. Tujuan penelitian ini adalah menentukan hubungan kolesterol LDL terhadap derajat retinopati diabetik di RSUP DR. M. Djamil Padang. Penelitian ini adalah studi analitik observasional dengan menggunakan desain cross sectional melalui pengumpulan data sekunder di bagian Instalasi Rekam Medis RSUP Dr. M. Djamil Padang periode Januari sampai Desember 2015. Jumlah sampel yang digunakan adalah 54 orang. Data yang diperoleh diuji menggunakan uji Mann-Whitney. Berdasarkan penelitian ini ditemukan rerata umur pasien retinopati diabetik adalah 57,02 (7,41) tahun. Jumlah pasien laki-laki dan perempuan sama banyak. Pada pasien dengan kolesterol LDL terkontrol ditemukan retinopati diabetik yaitu mild nonproliferative diabetic retinopathy (mild NPDR $)=57,1 \%$ dan moderate NPDR $=42,9 \%$. Pada pasien dengan kolesterol LDL tidak terkontrol ditemukan retinopati diabetik yaitu mild NPDR (32,5\%), moderate NPDR (27,5\%), severe NPDR (12,5\%) dan ditemukan proliferative diabetic retinopathy (PDR) dengan derajat early $=5,0 \%$ dan high risk $=22,5 \%$. Hasil analisis bivariat menunjukkan nilai signifikansi $\mathrm{p}<0,015$. Berdasarkan hasil ini dapat disimpulkan bahwa terdapat hubungan yang bermakna antara kolesterol LDL terhadap derajat retinopati diabetik.
\end{abstract}

Kata kunci: derajat retinopati diabetik, kolesterol LDL

\section{Abstract}

Diabetic retinopathy is one of the microvascular complications of DM which cause blindness in adults. Loss of the perisite is the beginning of diabetic retinopathy that can be affected by $L D L$ modification. The objective of this study was to determine the relationship between $L D L$ cholesterol and the degree of diabetic retinopathy in RSUP Dr. M. Djamil Padang. This research was an observational analytic with cross sectional design by collecting secondary data in Medical Record Installation RSUP DR. M. Djamil Padang from January to December 2015. The sample consisted of 54 people which taken using consecutive sampling technique. The data was tested by Mann-Whitney test. The analysis showed the average age of diabetic retinopathy patients was 57.02 (7.41) years old. The number of male and female patients were the same. Patients with controlled LDL cholesterol, diabetic retinopathy was found in mild NPDR (57.1\%) and moderate NPDR (42.9\%). In patients with uncontrolled LDL cholesterol, diabetic retinopathy was found in mild NPDR (32.5\%), moderate NPDR (27.5\%) and severe NPDR (12.5\%) while in PDR was found with early risk (5.0\%) and high risk (22.5\%). The result of bivariate analysis showed significance value with $p<0,015$. It is concluded that there is a significant relationship between $L D L$ cholesterol with the degree of diabetic retinopathy.

Keywords: degree of diabetic retinopathy, LDL cholesterol

Affiliasi penulis: 1. Prodi Kedokteran Fakultas Kedokteran Universitas Andalas Padang (FK Unand), 2. Bagian Mata FK Unand/RSUP Dr. M. Djamil Padang, 3. Bagian Pendidikan Kedokteran FK Unand
Korespondensi: Zacky Aulia Mursi, Email: zackymursi@gmail.com, Telp: 081266216380 


\section{PENDAHULUAN}

Diabetes melitus (DM) adalah suatu kelompok penyakit metabolik dengan karakter yaitu hiperglikemik yang terjadi karena kelainan kerja insulin, sekresi insulin atau keduanya. ${ }^{1}$ Jumlah pasien DM diseluruh dunia saat ini diperkirakaan lebih dari 360 juta orang dan diperkirakan akan naik lebih dari dua kali lipat pada tahun 2030. World Health Organization (WHO) memprediksi di Indonesia akan terjadi kenaikan jumlah penyandang DM dari 8,4 juta pada tahun 2000 menjadi sekitar 21,3 juta pada tahun $2030 .^{2}$

Resistensi insulin pada DM dapat menyebabkan dislipidemia. Gambaran dislipidemia pada DM yang paling sering ditemukan adalah peningkatan kadar trigliserida dan penurunan kadar kolesterol HDL (High Density Lipoprotein). Kadar kolesterol LDL (Low Density Lipoprotein) tidak selalu meningkat, tetapi partikel kolesterol LDL akan mengalami penyesuaian perubahan (modifikasi) menjadi bentuk kecil dan padat yang bersifat aterogenik. $^{3}$

Dislipidemia didefinisikan sebagai kelainan metabolisme lipid dimana terjadi peningkatan maupun penurunan komponen lipid dalam darah. Kelainan komponen lipid yang utama adalah kenaikan kadar kolesterol total, kolesterol LDL, trigliserida, serta penurunan kolesterol HDL. ${ }^{4}$

Peningkatan lipid serum dapat mengakibatkan komplikasi makrovaskuler (penyakit jantung iskemik) dan mikrovaskuler (retinopati diabetik). ${ }^{5}$ Retinopati diabetik merupakan gangguan penglihatan yang disebabkan karena adanya kelainan pada retina. Dimana terjadi suatu mikroangiopati progresif yang ditandai oleh kerusakan dan sumbatan pembuluhpembuluh darah halus sehingga mengakibatkan gangguan nutrisi pada retina. ${ }^{6}$

Di Indonesia, berdasarkan hasil penelitian The DiabCare Asia 2008 Study dilaporkan bahwa 42\% dari 1785 penderita DM di 18 pusat kesehatan di Indonesia mengalami komplikasi retinopati. ${ }^{7}$ Penelitian yang pernah dilaksanakan di RSUP Dr. M. Djamil tahun 2002 pada 377 orang penderita DM selama 4 bulan didapatkan bahwa jumlah penderita retinopati diabetik sebanyak 191 orang. $^{8}$
Retinopati adalah salah satu komplikasi mikrovaskular DM yang merupakan penyebab utama kebutaan pada orang dewasa. ${ }^{9}$ WHO tahun 2004 seperti yang dikutip oleh Suyono (2014) melaporkan 4,8 persen penduduk di seluruh dunia menjadi buta akibat retinopati diabetik. Dalam urutan penyebab kebutaan secara global, retinopati diabetik menempati urutan ke-4 setelah katarak, glaukoma, dan degenerasi makula (AMD=age-related macular degeneration). ${ }^{10}$

Perisit merupakan bagian penting dari struktur kapiler dan fungsi retina, dan kehilangan perisit adalah awal dari retinopati diabetik. ${ }^{11}$ Modifikasi LDL dapat mempengaruhi Human Retinal Capillary Pericytes (HRCP) yang dimediasi oleh peningkatan stres oksidatif, stres retikulum endoplasma, disfungsi mitokondria dan autofagi, sehingga menyebabkan apoptosis sel epitel pigmen retina. ${ }^{12}$

Studi oleh Wu et al (2008) melaporkan bahwa ekstravasasi dan oksidasi LDL berhubungan dengan peningkatan keparahan retinopati diabetik. ${ }^{13}$ Penelitian lain melaporkan bahwa kolesterol total, kolesterol LDL, dan kolesterol HDL berhubungan dengan retinopati diabetik proliferatif, namun tidak demikian dengan trigliserida. $^{14,15}$

Berdasarkan beberapa penelitian yang telah dilakukan di atas dan belum adanya data epidemiologi terbaru, perlu dilakukan sebuah penelitian mengenai hubungan kolesterol LDL dengan derajat retinopati diabetik di RSUP DR M. Djamil Padang.

\section{METODE}

Penelitian ini bersifat analitik observational yang bertujuan untuk mengetahui hubungan kolesterol LDL dengan derajat retinopati diabetik. Pendekatan yang dilakukan adalah studi komparatif dengan desain penelitian cross sectional study. Variabel independen pada penelitian ini adalah pemberian aktivitas fisik intensitas sedang terhadap subjek penelitian, sedangkan variabel dependennya adalah jumlah leukosit total sebelum dan sesudah melakukan aktivitas fisik intensitas sedang dan peningkatan jumlah leukosit total pada subjek laki-laki dan perempuan. Penelitian dilakukan dari November 2016 
hingga Maret 2017 di Instalasi Rekam Medik RSUP Dr. M. Djamil Padang.

Populasi penelitian adalah semua pasien retinopati diabetik yang berobat ke Poliklinik Mata RSUP Dr. M. Djamil Padang dari Januari sampai Desember 2015 yang berjumlah 183 orang. Sampel penelitian yang dipilih adalah 54 orang yang memenuhi kriteria inklusi dan eksklusi.

Data diperoleh dari rekam medik pasien retinopati diabetik yang berobat ke Poliklinik Mata RSUP Dr. M. Djamil Padang bulan Januari sampai Desember 2015 yang dievaluasi sesuai dengan kriteria inklusi dan eksklusi. Data yang memenuhi kriteria inklusi dan eksklusi lalu dilihat hasil laboratorium lipid darah dan dipisahkan sesuai kategori kolesterol LDL terkontrol dan kolesterol LDL tidak terkontrol. Setelah evaluasi, data tersebut dicatat untuk diolah dan dianalisis.

Data dianalisis secara statistik menggunakan sistem komputerisasi. Analisis univariat dilakukan untuk melihat distribusi frekuensi dan persentase yaitu meliputi usia, jenis kelamin, dan angka kejadian retinopati diabetik. Analisis bivariat dilakukan untuk menganalisis hubungan antara variabel dengan menggunakan uji Mann-Whitney dan, dikatakan bermakna bila $\mathrm{p}<0.05$.

\section{HASIL}

Penelitian analitik observasional yang dilakukan di Instalasi Rekam Medik RSUP Dr. M. Djamil Padang pada bulan Maret sampai April 2017 memperoleh 54 pasien retinopati diabetik yang memenuhi kriteria inklusi dan eksklusi.

\section{Data Penelitian}

Tabel 1. Karakteristik umum sampel penelitian

\begin{tabular}{lll}
\hline \multicolumn{1}{c}{ Variabel } & $\mathbf{n}$ & $\%$ \\
\hline Usia (tahun) & & \\
$25-44$ & 3 & 5,6 \\
$45-65$ & 45 & 83,3 \\
$>65$ & 6 & 11,1 \\
Jenis Kelamin & & \\
$\quad$ Laki-laki & 27 & 50,0 \\
Perempuan & 27 & 50,0 \\
\hline
\end{tabular}

Berdasarkan Tabel 1 diketahui bahwa sebagian besar pasien retinopati diabetik di Poliklinik Mata RSUP Dr. M. Djamil Padang berusia 45 sampai 65 tahun dan jarang ditemukan pasien yang lebih dari 65 tahun. Diketahui juga bahwa penderita retinopati diabetik yang perempuan dan laki-laki jumlahnya sama yaitu masing-masing $50 \%$.

Tabel 2. Distribusi frekuensi derajat retinopati diabetik

\begin{tabular}{lll}
\hline Derajat & $\mathbf{n}$ & $\%$ \\
\hline NPDR & & \\
Mild & 21 & 38,9 \\
Moderate & 17 & 31,5 \\
Severe & 5 & 9,3 \\
PDR & & \\
Early & 2 & 3,7 \\
High Risk & 9 & 16,7 \\
\hline
\end{tabular}

Hasil penelitian berdasarkan Tabel 2 menunjukkan bahwa kejadian terbanyak retinopati diabetik adalah mild NPDR sebanyak 38,9\%. Sedangkan yang paling jarang yaitu early PDR (3,7\%).

\section{Analisis Univariat}

Tabel 3. Derajat retinopati diabetik berdasarkan kolesterol LDL

\begin{tabular}{|c|c|c|c|c|c|c|c|c|c|c|}
\hline \multirow{3}{*}{ Kolesterol LDL } & \multicolumn{6}{|c|}{ NPDR } & \multicolumn{4}{|c|}{ PDR } \\
\hline & \multicolumn{2}{|l|}{ Mild } & \multicolumn{2}{|c|}{ Moderate } & \multicolumn{2}{|c|}{ Severe } & \multicolumn{2}{|c|}{ Early } & \multicolumn{2}{|c|}{ High Risk } \\
\hline & $\mathbf{n}$ & $\%$ & $\mathbf{n}$ & $\%$ & $\mathbf{n}$ & $\%$ & $\mathbf{n}$ & $\%$ & $\mathbf{n}$ & $\%$ \\
\hline Terkontrol & 8 & 57,1 & 6 & 42,9 & 0 & 0 & 0 & 0 & 0 & 0 \\
\hline Tidak Terkontrol & 13 & 32,5 & 11 & 27,5 & 5 & 12,5 & 2 & 5,0 & 9 & 22,5 \\
\hline
\end{tabular}

Keterangan: NPDR = Nonproliferative Diabetic Retinopathy PDR = Proliferative Diabetic Retinopathy 
Tabel 3 menunjukkan bahwa pada pasien yang kolesterol LDL terkontrol ditemukan retinopati diabetik yaitu mild NPDR sebesar $57,1 \%$ dan moderate NPDR sebesar $42,9 \%$, tetapi tidak ditemukan PDR baik early maupun high risk. Pada pasien yang memiliki kadar kolesterol LDL tidak terkontrol ditemukan retinopati diabetik yaitu mild NPDR sebesar $32,5 \%$, moderate NPDR sebesar $27,5 \%$, severe NPDR sebesar $12,5 \%$ dan ditemukan PDR dengan derajat early sebesar $5,0 \%$ dan high risk sebesar $22,5 \%$.

\section{Analisis Bivariat}

Tabel 4. Hubungan kolesterol LDL dengan Derajat Retinopati Diabetik

\begin{tabular}{|c|c|c|c|c|c|c|c|c|c|c|c|}
\hline \multirow{3}{*}{ Kolesterol LDL } & \multicolumn{6}{|c|}{ NPDR } & \multicolumn{4}{|c|}{ PDR } & \multirow{3}{*}{$\mathbf{p}$} \\
\hline & \multicolumn{2}{|c|}{ Mild } & \multicolumn{2}{|c|}{ Moderate } & \multicolumn{2}{|c|}{ Severe } & \multicolumn{2}{|c|}{ Early } & \multicolumn{2}{|c|}{ High Risk } & \\
\hline & $\mathbf{n}$ & $\%$ & $\mathbf{n}$ & $\%$ & $\mathbf{n}$ & $\%$ & $\mathbf{n}$ & $\%$ & $\mathbf{n}$ & $\%$ & \\
\hline Terkontrol & 8 & 57,1 & 6 & 42,9 & 0 & 0 & 0 & 0 & 0 & 0 & \\
\hline Tidak Terkontrol & 13 & 32,5 & 11 & 27,5 & 5 & 12,5 & 2 & 5,0 & 9 & 22,5 & 0,015 \\
\hline
\end{tabular}

Keterangan: NPDR $=$ Nonproliferative Diabetic Retinopathy PDR $=$ Proliferative Diabetic Retinopathy

Berdasarkan Tabel 4 dapat dilihat bahwa hubungan kolesterol LDL dengan derajat retinopati diabetik memiliki tingkat signifikansi $(p)<0,015$, sehingga dapat disimpulkan bahwa terdapat hubungan yang bermakna antara kolesterol LDL dengan derajat retinopati diabetik.

\section{PEMBAHASAN}

Berdasarkan penelitian yang dilakukan pada pasien retinopati diabetik yang berobat ke Poliklinik Mata RSUP Dr. M. Djamil Padang periode Januari sampai Desember 2015, sebagian besar pasien retinopati diabetik yaitu 45 sampai 65 tahun, sedangkan kejadiannya menurun pada usia lebih dari 65 tahun. Hal ini sesuai dengan penelitian yang dilakukan oleh Raman et al tahun 2009 yang melaporkan bahwa pasien retinopati diabetik lebih sering pada usia 50 sampai 59 tahun dan menurun mulai dari usia 60 tahun. ${ }^{16}$ Hal tersebut dikarenakan bahwa dengan peningkatan usia dapat menurunkan fungsi tubuh yang disebabkan oleh karena proses apoptosis sel yang dimulai dari usia 45 tahun. ${ }^{17}$ Alasan mengapa jumlah penderita retinopati kembali menurun pada usia diatas 60 tahun karena kemungkinan sudah sakit berat sehingga tidak bisa ke rumah sakit untuk berobat ataupun dikarenakan pasien sudah meninggal. ${ }^{17}$
Tabel 1 menunjukkan tidak didapatkan perbedaan antara pasien laki-laki dan perempuan yang menderita retinopati diabetik. Dari 54 pasien yang diteliti, penderita retinopati diabetik yang perempuan dan laki-laki jumlahnya sama yaitu masingmasing 50\%. Berbeda dengan penelitian $\mathrm{He}$ et al tahun 2012 yang melaporkan kejadian retinopati diabetik lebih sering pada laki-laki yaitu $52,4 \%{ }^{18}$ Perbedaan hasil ini mengindikasikan bahwa pengaruh yang ditimbulkan oleh jenis kelamin laki-laki atau perempuan terhadap retinopati diabetik tidak terlalu bermakna.

Pada Tabel 2 diketahui bahwa derajat retinopati diabetik tersering pada pasien yang berobat ke Poliklinik Mata RSUP Dr. M. Djamil Padang adalah mild NPDR. Hal ini sesuai dengan Henricsson et al pada tahun 2003 yang melaporkan kejadian terbanyak retinopati diabetik berdasarkan derajatnya adalah mild NPDR. ${ }^{19}$

Hasil penelitian yang tercantum pada Tabel 3 dapat dilihat bahwa risiko menderita dan derajat keparahan retinopati diabetik meningkat seiring dengan kontrol kolesterol LDL yang buruk. Pada pasien kolesterol LDL terkontrol ditemukan kejadian retinopati diabetik, yaitu derajat mild NPDR sebesar $57,1 \%$ dan moderate NPDR sebesar $42,9 \%$, pada PDR tidak ditemukan baik derajat early maupun high 
risk. Pasien dengan PDR terlihat pada pasien kolesterol LDL tidak terkontrol. Hal ini tidak sesuai dengan penelitian Rianita et al pada tahun 2008 yang menyatakan bahwa sudah ditemukan PDR sebanyak $40 \%$ pada pasien kolesterol LDL terkontrol. ${ }^{20}$ Perkembangan retinopati diabetik dapat ditemukan tergantung keutuhan BRB serta ekstravasasi dan oksidasi LDL yang terjadi pada kapiler retina. ${ }^{13}$

Berdasarkan hasil analisis statistik dengan menggunakan uji Mann-Whitney seperti yang tercantum pada Tabel 4 didapatkan tingkat signifikansi $\mathrm{p}<0,015$ yang menunjukkan bahwa terdapat hubungan yang bermakna antara kedua variabel dan berbanding lurus yaitu semakin tidak terkontrol kolesterol LDL maka semakin tinggi derajat retinopati diabetiknya. Hal ini sesuai dengan penelitian Kissebah et al tahun 1975 yang melaporkan terjadinya peningkatan derajat retinopati diabetik dengan peningkatan profil lipid plasma terutama kolesterol LDL $(p<0,001){ }^{21}$

Hubungan antara kolesterol LDL dengan keterpaparan faktor risiko lain mengiringi perubahan patologis yang terjadi di pembuluh darah retina. Modifikasi LDL dapat mempengaruhi Human Retinal Capillary Pericytes (HRCP) yang dimediasi oleh peningkatan stres oksidatif, stres retikulum endoplasma, disfungsi mitokondria dan autofagi. Sehingga menyebabkan apoptosis sel epitel pigmen retina. $^{12}$ Modifikasi LDL dapat berupa oxidized LDL (oxLDL). ${ }^{22}$

Perisit merupakan bagian penting dari struktur kapiler dan fungsi retina, dan kehilangan perisit adalah awal dari retinopati diabetik. ${ }^{11}$ Kehilangan perisit mendasari kebocoran pada Blood-Retinal Barrier (BRB). ${ }^{21}$

Du et al pada tahun 2013 menunjukkan bahwa dalam sel epitel pigmen retina, oxLDL menginduksi produksi reactive oxygen species (ROS) dan menurunkan kadar glutathione peroxidase 1 (GPX-1). Terlalu banyak produksi ROS menyebabkan stres oksidatif, sehingga menyebabkan kerusakan dan kematian sel kapiler retina. $^{22}$

Retikulum endoplasma mempunyai fungsi penting, termasuk dalam sintesis lipid dan protein. Terjadinya stres retikulum endoplasma dapat menyebabkan kematian neuron retina dan sel-sel pembuluh darah. Disfungsi mitokondria juga terlibat dalam hilangnya perisit diinduksi oleh hiperglikemia. ${ }^{22}$

Beberapa studi telah menunjukkan bahwa autofagi tidak hanya merupakan proses perbaikan dengan menghilangkan sel-sel debris dan mengurangi stres retikulum endoplasma, tetapi juga dapat menyebabkan kematian sel jika stres retikulum endoplasma berkepanjangan. ${ }^{22}$

$\mathrm{Wu}$ et al (2008) menunjukkan bahwa ekstravasasi dan oksidasi LDL berhubungan dengan peningkatan keparahan retinopati diabetik. ${ }^{13}$ Penelitian lain melaporkan bahwa kolesterol total, kolesterol LDL, dan kolesterol HDL berhubungan dengan retinopati diabetik proliferatif, namun tidak demikian dengan trigliserida. $^{14,15}$

\section{SIMPULAN}

Terdapat hubungan yang bermakna antara kolesterol LDL dengan derajat retinopati diabetik, yaitu terjadinya peningkatan derajat retinopati diabetik pada kolesterol LDL tidak terkontrol dibanding yg terkontrol.

\section{DAFTAR PUSTAKA}

1. American Diabetes Association. Diagnosis and classification of diabetes mellitus. Diabetes Care. 2010;33:62-9.

2. International Diabetes Federation (IDF). Definition and diagnosis of diabetes mellitus and intermediate hyperglicaemia. 2013 (diunduh 10 September 2016. Tersedia dari: http://www.idf.org/webdata/ docs/WHO IDF definition diagnosis of diabetes. pdf

3. Suhartono T. Dislipidemia pada diabetes melitus. Dalam: Darmono, editor (penyunting). Naskah lengkap diabetes mellitus ditinjau dari berbagai aspek penyakit dalam dalam rangka purna tugas Prof Dr.dr.RJ Djokomoeljanto. Semarang: Badan Penerbit Universitas Diponegoro; 2007.hlm.31-5.

4. Perkeni. Konsensus pengelolaan dislipidemia di Indonesia. Jakarta: Pusat Penerbitan IImu Penyakit Dalam Fakultas Kedokteran Universitas Indonesia. 2012. 
5. Mathur A, Mathur R. Study of association of serum lipids with diabetic retinopathy in type 2 diabetes mellitus. People's Journal of Scientific Research. 2013;6(1):25-7.

6. Ilyas S. IImu penyakit mata. Edisi ke-3. Jakarta: BP FK UI. 2008.hlm.218-20.

7. Soewondo, Pradana, Soegondo, Sidartawan, Suastika, Ketut, et al. The diabcare Asia 2008 study - outcomes on control and complications of type2 diabetic patients in Indonesia. Med $J$ Indones. 2010;19(4):235-44.

8. Edwina DA. Pola komplikasi kronis penderita diabetes melitus tipe 2 rawat inap di bagian penyakit dalam RS Dr. M. Djamil Padang (skripsi). Padang: Fakultas Kedokteran Universitas Andalas; 2012.

9. Sitompul R. Retinopati diabetik. Journal of The Indonesian Medical Association. 2011;61:337-41.

10. Suyono S. Diabetes melitus di Indonesia. Dalam: Setiati S, Alwi I, Sudoyo AW, Simadibrata M, Setiyohadi B, Syam AF, editor (penyunting). Buku ajar ilmu penyakit dalam jilid II. Edisi ke-6. Jakarta: Interna Publishing. 2014.hlm.2315-21.

11. Fu D, Wu M, Zhang J, Du M, Yang S, Hammad $\mathrm{SM}$, et al. Mechanisms of modified LDL - Induced pericyte loss and retinal injury in diabetic retinopathy. Diabetologia. 2012;55:3128-40.

12. Baynes JW, Thorpe SR. Role of oxidative stress in diabetic complicatios: A new perspective on an old paradigm. Diabetes. 1999;48:1-9.

13. Wu M, Chen Y, Wilson K. Intraretinal leakage and oxidation of LDL in diabetic retinopathy. Invest Ophthalmol Vis Sci. 2008;49:2679-85.

14. DaSilva ZM, Freitas AM, Marcon IM. Risk factors related to severity of diabetic retinopathy. Arq Bras Opthalmol. 2003;66:739-43.

15. Su DHW, Yeo KT. Diabetic retinopathy and serum lipids. Singapore Med J. 2000;41:295-7.

16. Raman R, Rani SR, Rachepalle P, Gnanamoorthy S, Uthra G, Kumaramanickavel PK, et al. Prevalence of diabetic retinopathy in India. Ophtalmology Journal. 2009;116:311-8.

17. Kowluru RA, Menon B, Giehart J. Metabolic abnormalities in diabetic patients. Investigative Ophtalmol and Visual Science J. 2010;49:164-71.

18. He B, Wei Y, Gu J, Han Y, Liu Y, Bao L, et al. Factors associated with diabetic retinopathy in chinese patients with type 2 diabetes mellitus. Int $\mathrm{J}$ Endocrinol. 2012;2012:157940.

19. Henricsson M, Nystrom L, Blohme G, Ostman J, Kullberg C, Svensson M, et al. The incidence of retinopathy 10 years after diagnosis in young adult people with diabetes: results from the nationwide population-based Diabetes Incidence Study in Sweden (DISS). Diabetes Care. 2003;26(2):34954.

20. Rianita, Bardosono S, Victor AA. Relationship between plasma lipid profile and the severity of diabetic retinopathy in type 2 diabetes patients. Med J Ind. 2008;17(4):221-5.

21. Kissebah AH, Siddiq YK, Kohner EM, Lowy C, Lewis B, Fraser TR. Plasma lipids and glucose/insulin relationship in non insulin requiring diabetics with and without retinopathy. Lancet. 1975;1(7916):1104-8.

22. Du M, Wu M, Fu D, Yang S, Chen J, Wilson K, et al. Effects of modified LDL and HDL on retinal pigment epithelial cells: $A$ role in diabetic retinopathy?. Diabetologia. 2013; 56:2318-28. 